\title{
Variation in xylem structure and function in roots and stems of scion-rootstock combinations of sweet cherry tree (Prunus avium L.)
}

\author{
Berta Gonçalves • Carlos M. Correia • Ana Paula Silva • \\ Eunice A. Bacelar • Alberto Santos · Helena Ferreira • \\ José M. Moutinho-Pereira
}

Received: 1 June 2006 / Revised: 22 August 2006 / Accepted: 27 October 2006 / Published online: 14 December 2006

(C) Springer-Verlag 2006

\begin{abstract}
To assess hydraulic architecture and limitations to water transport across scion-rootstock combinations (Prunus avium L. cultivar Van grafted on five differing size-controlling rootstocks: $P$. avium (vigorous) $>\mathrm{CAB}$ $11 \mathrm{E}>$ Maxma $14>$ Gisela $5>$ Edabriz (dwarfing)), we compared xylem anatomy, and calculated relative hydraulic conductivity (RC) and vulnerability index (VI) of roots (small, medium and large diameter) and stems. Water relations, leaf gas exchange and variations in growth were also determined. Roots exhibited larger-diameter xylem conduits (VD), greater RC and VI than stems in all Van-rootstock combinations. Moreover, there was a significantly higher vessel frequency (VF), lower VD, RC and VI in dwarfed trees, especially grafted on Gisela 5 than trees on the invigorating rootstocks, $P$. avium L., CAB $11 \mathrm{E}$ and Maxma 14. Anatomical constraints on water status imposed by the smaller VD (and/or in lower xylem thickness and root system length) of dwarfed trees imply a series of negative feedbacks, like a decrease in RC, stem water potential, leaf gas exchange and growth. On the other hand, Van grafted on CAB $11 \mathrm{E}$ and
\end{abstract}

Communicated by M. Zwieniecki

B. Gonçalves · C. M. Correia · E. A. Bacelar · H. Ferreira .

J. M. Moutinho-Pereira $(\square)$

CETAV - Centre for Technological, Environmental and Life

Studies, Department of Biological and Environmental

Engineering, University of Trás-os-Montes e Alto Douro,

Apartado 1013,

5001-801 Vila Real, Portugal

e-mail:moutinho@utad.pt

A. P. Silva $\cdot$ A. Santos

CECEA - Research Centre for Agricultural Sciences and

Engineering, Department of Plant Science and Agricultural

Engineering, University of Trás-os-Montes e Alto Douro,

Apartado 1013,

5001-801 Vila Real, Portugal
Maxma 14, with wide vessels and high VI, could be more susceptible to embolism, especially during periods of severe water stress, than trees on dwarfing rootstocks, which had small vessels and low VI.

Keywords Plant water transport - Relative hydraulic conductivity · Rootstock effects · Vulnerability to cavitation $\cdot$ Whole-tree hydraulic architecture $\cdot$ Xylem anatomy

\section{Introduction}

Variations in xylem anatomy and hydraulic properties occur at several levels: interspecific, intraspecific and intraplant (Zimmermann 1983; Ewers 1985; Tyree and Ewers 1991; Sperry and Saliendra 1994; Jackson et al. 2000). Moreover, variations in xylem conduit diameter can radically affect the conducting system according to the fourth-power relationship between radius and flow through a capillary tube, as described by the Hagen-Poiseuille law (Zimmermann 1983; Tyree and Ewers 1991). Thus, even a small increase in mean conduit diameter has exponential effects on specific hydraulic conductivity $\left(K_{\mathrm{s}}\right)$. Consistent with this theory, numerous studies have shown that $K_{\mathrm{s}}$ is higher in shallow roots than in stems (Alder et al. 1996; Kavanaugh et al. 1999; Martínez-Vilalta et al. 2002; McElrone et al. 2004). Other studies reported a decline in whole-plant hydraulic conductance with height (Mencuccini and Grace 1996; Ryan et al. 2000; McDowell et al. 2002). According to Lovisolo and Schubert (1998), $K_{\mathrm{s}}$ can change as a result of (1) modifications of the size of the xylem vessels or (2) interruption of the water column in the vessels by embolism.

Clonal rootstocks of cherry tree are widely used to control the vegetative vigour of the trees and improve fruit quality. 
The mechanisms for these commercially useful rootstock effects are complex and poorly understood, but a common hypothesis is that rootstocks that reduce scion vigour have low hydraulic conductance (Syvertsen and Graham 1985; Atkinson and Else 2001). According to Baas et al. (1984), in various dwarf trees there is a strong correlation between tree height and vessel element size. However, this correlation must be treated with caution, since water movement and balance are not only regulated by anatomical characteristics. They may also be influenced by water potential gradients within the plant, as well as stomatal features and their sensitivity, especially when water availability is limited in the soil (Reyes-Santamaría et al. 2002).

A restriction of water flow is entirely consistent with the anatomical changes associated with graft tissues and the different degrees of shoot dwarfism showed in grafted plants (Simons 1986; Soumelidou et al. 1994; Sekse 1998). Several authors have reported morphological alterations, namely small vessels and swirling of vascular tissue (Soumelidou et al. 1994), and presence of necrotic areas and large amounts of non-conducting phloem (Simons and Chu 1984) in the graft union of apple trees grafted onto dwarfing rootstocks. These anatomical changes may be due to limitations in polar auxin (IAA) transport across the graft and its accumulation at the graft (Simons 1986; Soumelidou et al. 1994). IAA is a key leaf-derived regulator of xylem cell differentiation and division within the cambial zone and an initiator of vascular redifferentiation across the graft union (Hess and Sachs 1972; Parkinson and Yeoman 1982; Aloni 1987; Savidge 1988). A reduced flow of IAA to roots could provide an explanation to the lower xylem/phloem ratio presented by the trees grafted on dwarfing rootstocks, compared with trees on invigorating rootstocks (Simons 1986; Kurian and Iyer 1992).

Xylem water transport in plants is the subject of intensive research because of its agronomic and ecological implications (Lovisolo and Schubert 1998). On the one hand, the aim of investigations focused on crop water management is to improve water use efficiency (Jones 1990), whilst on the other hand, factors affecting water transport parameters are important determinants of drought tolerance and relative habitat preferences of native and cultivated species (Sperry and Tyree 1990; Cochard et al. 1994; Pockman et al. 1995), and predictors of carbon and water balance in environmental models (Williams et al. 1996).

Development of the concept of hydraulic architecture by Zimmermann $(1978,1983)$ has led to numerous studies of the structure and properties of the water transport system of trees that govern the balance between efficiency of water supply and total transpiring leaf area (e.g., Ewers and Zimmermann 1984; Tyree et al. 1991). In particular, water uptake and transport through the xylem are essential for replacing water lost during transpiration, preventing desiccation, and allow- ing continued photosynthesis (Kramer and Boyer 1995). In a previous study, we demonstrated that water relations and leaf gas exchange of sweet cherry tree were mainly influenced by the rootstock genotype (Gonçalves et al. 2006). However, we know of no previous data related to xylem structure and function of different diameter roots, rootstock stems and scion stems in sweet cherry, which can help us to explain that behaviour. Therefore, in this study, the purpose was to test the hypothesis that reduced hydraulic conductance can provide an explanation for reductions in plant vigour caused by rootstocks. Specifically, the experiment was designed to determine secondary xylem anatomical variation, relative hydraulic conductivity (RC) and vulnerability index (VI), water potential, leaf gas exchange and growth in cultivar Van grafted on five differing size-controlling rootstocks: $P$. avium, CAB 11E, Maxma 14, Gisela 5 and Edabriz, growing in natural field conditions.

\section{Material and methods}

Plant material and growth conditions

The study was carried out on adult plants of $P$. avium in an experimental plot near Vila Real, northeast Portugal $\left(41^{\circ} 19^{\prime} \mathrm{N}\right.$ and $7^{\circ} 44^{\prime} \mathrm{W}$; altitude $470 \mathrm{~m}$ above sea level), between 1997 and 2002, as described in Gonçalves et al. (2003, 2006). Briefly, sweet cherry trees used in the field experiment were a mid to late maturing cultivar Van grafted on five different rootstocks: P. avium (vigorous), CAB 11E (clone of Prunus cerasus L.; semi-vigorous) Maxma 14 (P. avium $\times$ Prunus mahaleb L. hybrid; semi-dwarfing), Gisela 5 (P. cerasus $\times$ Prunus canescens Bois hybrid; dwarfing) and Edabriz (clone of $P$. cerasus; very dwarfing). Two representative trees of each Van-rootstock combination were randomly selected to make all the measurements.

In 1997, rootstocks were planted in the nursery. After grafting in 1999, trees were transplanted in a north-south orientation with rows $5.5 \mathrm{~m}$ apart. Within rows, trees were spaced according to the vigour of the rootstock: 5.5, 5.0, 4.5, 4.0 and 3.0 for P. avium, CAB 11E, Maxma 14, Gisela 5 and Edabriz, respectively.

Routine disease and pest control treatments were provided according to a commercial protocol for fruit production. The cherry orchard was fertilized and daily drip-irrigated $(3 \mathrm{~h}$, between May and September; drippers were in line, $1 \mathrm{~m}$ apart, and $4 \mathrm{l} \mathrm{h}^{-1}$ flow rate). The trees were not pruned during the experiment.

Xylem anatomical analyses and electron micrographs

From each of two replicate plants used, per rootstock, 15 stems and 15 fine $(\varnothing<2 \mathrm{~mm})$, medium $(\varnothing, 2-5 \mathrm{~mm})$ and 
large $(\varnothing>5 \mathrm{~mm})$ roots were removed in 1997 for microscopic investigation of xylem anatomy. In 2001 and 2002, 15 stems were collected from each of two plants per scionrootstock combination for light microscopic investigation of xylem anatomy. One year old stem transverse sections, approximately $50 \mu \mathrm{m}$ thick, were dissected at the same distance from the apex $(10 \mathrm{~cm})$ with a hand microtome, roots were also cut, stained in a combination of alum carmine and iodine green (Deysson 1965) and then mounted with synthetic resin. This double staining brought out the lignified elements in green and the cellulose in pink. Measurements of xylem vessel frequency and xylem vessel diameter were made on each cross section. Vessel frequency (vessels $\mathrm{mm}^{-2}$ ) represents the mean of 30 randomly fields of view per treatment and each vessel diameter $(\mu \mathrm{m})$ was determined from the mean of two orthogonal measurements across the widest part of the vessel lumen. Randomly selected vessels within the vascular pathway (i.e., area of maximum water transport) were chosen for measurement $(n=30)$. Efficiency and susceptibility to damage during water conduction was evaluated through relative hydraulic conductivity (Zimmermann 1983) and vulnerability index (Carlquist 1977). The relative hydraulic conductivity was estimated using a modified HagenPoiseuille equation (Fahn et al. 1986): $\mathrm{RC}=r^{4} \mathrm{VF}$, where $\mathrm{RC}$ is the relative hydraulic conductivity, $r$ the individual vessel radius and VF the vessel frequency. The vulnerability index (VI) was calculated as proposed by Carlquist (1977): $\mathrm{VI}=\mathrm{VD} / \mathrm{VF}$, where $\mathrm{VD}$ is the vessel diameter and VF the vessel frequency.

For scanning electron microscopy (SEM) observations, transverse sections of roots and stems were performed as described above for xylem analysis. Micrographs of the different organs were obtained by SEM Philips/FEI Quanta 400 (Brno, Czech Republic).

Water relations and leaf gas exchange

Morning $\left(\Psi_{\mathrm{PD}}\right)$ and midday $\left(\Psi_{\mathrm{MD}}\right)$ stem water potentials of sweet cherry trees were determined with a pressure chamber (ELE International, Bedfordshire, U.K.) according to McCutchen and Schackel (1992). Stem water potential was measured on fully-expanded healthy leaves on June 21 and July 8, 2002. Previously, they were placed in a black polyethylene bag wrapped in aluminium foil for at least $90 \mathrm{~min}$ before measurements, to allow leaf water potential to equilibrate with stem water potential. In all cases, leaves were placed in the chamber within a few seconds after excision. Eight measurements of $\Psi$ were done by Van-rootstock combination, in each diurnal period and date.

Leaf gas exchange parameters were measured with a portable gas exchange system (ADC-LCA-3, Analytical Development, Hoddesdon, U.K.) and a leaf chamber clip (ADCPLC, surface: $6.25 \mathrm{~cm}^{2}$, volume: $16 \mathrm{~cm}^{3}$ ) with quantum, temperature and humidity sensors. The gas exchange unit was operated in the open mode at $300 \mathrm{ml} \mathrm{min}^{-1}$ flow rate and at ambient $\mathrm{CO}_{2}$ partial pressure of 35-37 Pa. Eight measurements were done on 'sun' fully-expanded healthy leaves in the morning (09.00-11.00 h) and afternoon (14.00-16.00 h). Net $\mathrm{CO}_{2}$ assimilation rate $(A)$ and stomatal conductance $\left(g_{\mathrm{s}}\right)$ were estimated from gas exchange measurements using the equations of von Caemmerer and Farquhar (1981). Measurements were conducted in cloudless days of summer, where the photosynthetic photon flux density ranged between 1850 and $1950 \mu \mathrm{mol} \mathrm{m} \mathrm{m}^{-2} \mathrm{~s}^{-1}$, air temperature ranged between 25 and $30^{\circ} \mathrm{C}$ and air vapour pressure deficits were around 2.6 and $3.1 \mathrm{kPa}$ in the morning and afternoon, respectively.

Plant growth parameters

Plant height and trunk diameters below (in the rootstock) and above (in the cultivar) the grafting points were measured in all plants between 1998 and 2002, in each dormancy period.

\section{Statistics}

One-way analysis of variance (ANOVA) was used to examine organ or rootstock effect on xylem hydraulic properties, water relations, leaf gas exchange and growth of cherry trees, and least significant difference tests were used to compare individual treatment means $(P<0.05)$. All data sets satisfied the assumptions of ANOVA based on homogeneity of variances, normality of errors, and independence of errors. Associations among characters were examined by a Fisher correlation analysis. The relationships between $A$ and $g_{\mathrm{s}}$,
Table 1 Means of xylem vessel diameter (VD), vessel frequency (VF), calculated relative hydraulic conductivity (RC) and vulnerability index (VI) of the different organs

Means $(n=150)$ followed by the same letter are not significantly different at $P<0.05$ (Duncan's test).

\begin{tabular}{|c|c|c|c|c|}
\hline Organ & $\mathrm{VD}(\mu \mathrm{m})$ & $\mathrm{VF}\left(\right.$ vessels $\mathrm{mm}^{-2}$ ) & $\mathrm{RC}\left(\mu \mathrm{m}^{4} 10^{6}\right)$ & VI \\
\hline Fine roots & $23.9 \mathrm{c}$ & $576.4 \mathrm{~d}$ & $15.44 \mathrm{c}$ & $55.9 \mathrm{~b}$ \\
\hline Medium roots & $34.2 \mathrm{e}$ & $348.8 \mathrm{~b}$ & $35.08 \mathrm{e}$ & $147.8 \mathrm{~d}$ \\
\hline Large roots & $32.9 \mathrm{~d}$ & $261.6 \mathrm{a}$ & $22.5 \mathrm{~d}$ & $155.8 \mathrm{e}$ \\
\hline Rootstock stem & $24.3 \mathrm{c}$ & $349.5 \mathrm{~b}$ & $8.76 \mathrm{~b}$ & $75.9 \mathrm{c}$ \\
\hline Scion stem (2001) & $14.0 \mathrm{~b}$ & $533.3 \mathrm{c}$ & $1.53 \mathrm{a}$ & $26.8 \mathrm{a}$ \\
\hline Scion stem (2002) & $12.8 \mathrm{a}$ & $524.7 \mathrm{c}$ & $1.05 \mathrm{a}$ & $25.4 \mathrm{a}$ \\
\hline$P$-value & 0.0001 & 0.0001 & 0.0001 & 0.0001 \\
\hline
\end{tabular}


plant height and rootstock stem diameter, and plant height and scion stem diameter were analysed by simple linear regression. The slopes and the equations of the linear regression of each rootstock were compared by $t$-test and Fisher's test, respectively.

\section{Results}

Xylem hydraulic properties

Vessel diameter (VD), vessel frequency (VF), and the calculated values of relative hydraulic conductivity $(\mathrm{RC})$ and vulnerability index (VI) were significantly $(P<0.001)$ related to organ (Table 1). The values of VD were significantly smaller in the scion stems, intermediate in rootstock stems, and larger in roots, mainly in those with medium diameter (Table 1). Medium size roots had mean VD that was 2.7 times larger than vessels from terminal shoots (Table 1). In relation to vessel frequency, the lowest VF was observed in large size roots and the highest in fine roots $(+120 \%)$.

In roots, a significant negative correlation was found between VD and VF, in all rootstocks, and the values of the coefficient of correlation $(r)$ varied between -0.35 and -0.72 $(P<0.001$; data not shown). However, there was no correlation between these two parameters in stems.

Medium-size roots (Table 1) had much higher RC (2620\%) than terminal shoots of Van, on average of the years 2001-2002 Table 4. As sampling depth increased, the greater proportion of large conduits in each distribution and the concurrent increased mean conduit diameter (Fig. 1) resulted in greater RC (Table 1). The VI of the cherry vessels ranged from 25 to 156 , where large roots had comparatively high values (Table 1).

Statistical analysis showed significant differences $(P<0.05)$ in VD, VF, RC and VI among rootstocks (Tables $2-4)$. VD values of all organs were significantly largest in invigorating plants, especially in CAB $11 \mathrm{E}$, which had a mean vessel diameter of $25 \mu \mathrm{m}, 45 \%$ larger than vessels of trees on Gisela 5 (Tables 2-4, Fig. 2). In general, the dwarfing Edabriz and Gisela 5 induced significantly higher VF than trees on invigorating rootstocks. On the other hand, the rootstock Gisela 5 induced the lowest RC and CAB 11E the highest. Notably, stems of Van on the dwarfing Edabriz had higher $\mathrm{RC}$ than those observed on invigorating Maxma 14 and $P$. avium. Among the five rootstocks studied (data not shown), Van on the dwarfing Gisela 5 and Edabriz had the lowest VI $(<40)$, intermediate values in P. avium (66) and highest in Maxma 14 and CAB 11E ( $>95$ ). In addition, dwarfed trees had significantly $(P<0.001)$ lower xylem/phloem thickness ratio than invigorating trees (Fig. 3), due to a low xylem thickness (data not shown).

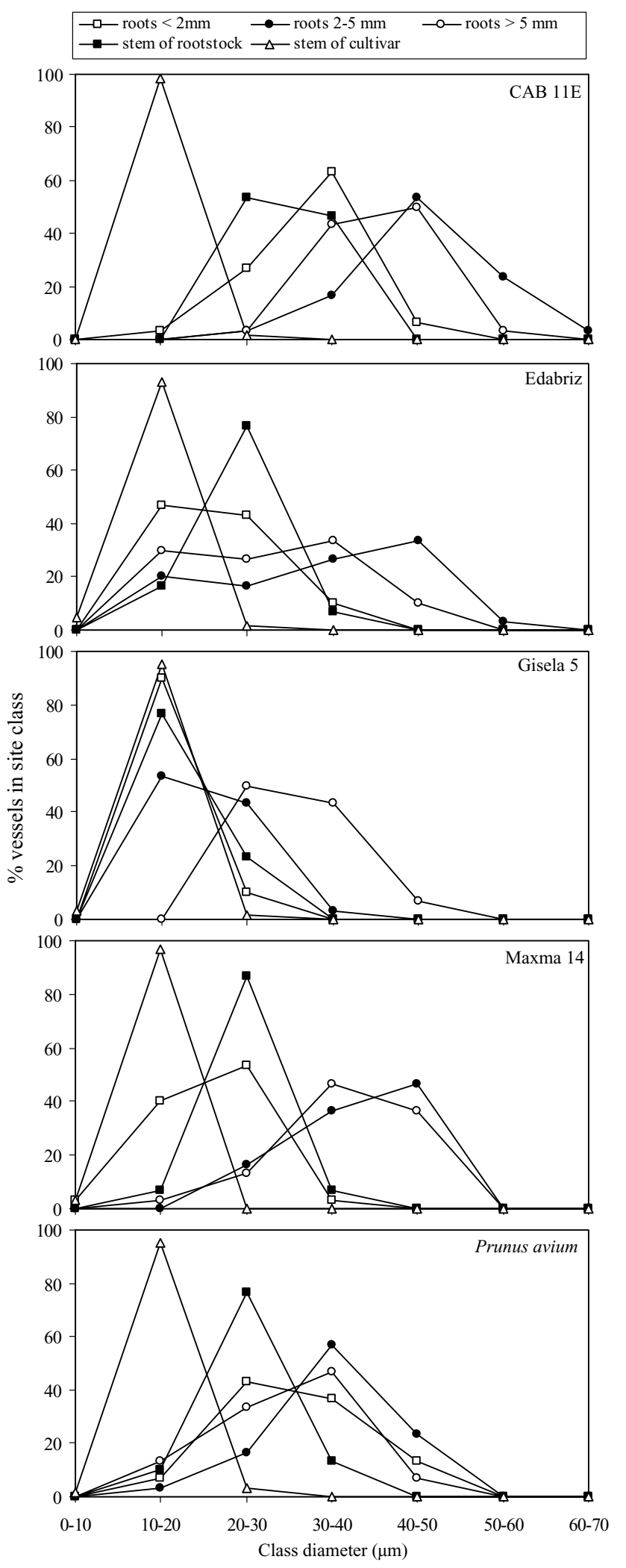

Fig. 1 Percentage of vessels per class diameter in organs of Van grafted onto five rootstocks 
Table 2 Xylem vessel diameter (VD), vessel frequency (VF), relative hydraulic conductivity (RC) and vulnerability index (VI) of the fine $(\varnothing<2 \mathrm{~mm})$, medium $(\varnothing, 2-5 \mathrm{~mm})$ and large $(\varnothing>5 \mathrm{~mm})$ roots of the five rootstocks in 1997

\begin{tabular}{|c|c|c|c|c|c|c|c|c|c|c|c|c|}
\hline \multirow[t]{2}{*}{ Rootstock } & \multicolumn{3}{|c|}{$\mathrm{VD}(\mu \mathrm{m})$} & \multicolumn{3}{|c|}{ VF (vessels mm ${ }^{-2}$ ) } & \multicolumn{3}{|c|}{$\mathrm{RC}\left(\mu \mathrm{m}^{4} 10^{6}\right)$} & \multicolumn{3}{|l|}{ VI } \\
\hline & $\bar{\varnothing}<2$ & $2-5$ & $\varnothing>5$ & $\overline{\varnothing<2}$ & $2-5$ & $\varnothing>5$ & $\overline{\varnothing<2}$ & $2-5$ & $\varnothing>5$ & $\overline{\varnothing<2}$ & $2-5$ & $\varnothing>5$ \\
\hline P. avium & $29.9 \mathrm{c}$ & $34.1 \mathrm{~b}$ & $29.1 \mathrm{a}$ & $292.5 \mathrm{a}$ & $198.2 \mathrm{a}$ & $347.3 \mathrm{bc}$ & $21.7 \mathrm{~b}$ & $20.7 \mathrm{a}$ & $21.3 \mathrm{ab}$ & $102.1 \mathrm{e}$ & $172.0 \mathrm{c}$ & $83.7 \mathrm{a}$ \\
\hline CAB 11E & $32.1 \mathrm{c}$ & $46.2 \mathrm{~d}$ & $40.0 \mathrm{~b}$ & $394.4 \mathrm{~b}$ & $192.5 \mathrm{a}$ & $173.6 \mathrm{a}$ & $31.8 \mathrm{c}$ & $62.9 \mathrm{c}$ & $30.7 \mathrm{~b}$ & $81.4 \mathrm{~d}$ & $239.8 \mathrm{~d}$ & $230.5 \mathrm{c}$ \\
\hline Maxma 14 & $20.8 \mathrm{~b}$ & $38.2 \mathrm{c}$ & $36.8 \mathrm{~b}$ & $400.1 \mathrm{~b}$ & $164.2 \mathrm{a}$ & $130.2 \mathrm{a}$ & $6.4 \mathrm{a}$ & $26.2 \mathrm{~b}$ & $17.6 \mathrm{a}$ & $52.0 \mathrm{c}$ & $232.6 \mathrm{~d}$ & $282.2 \mathrm{~d}$ \\
\hline Gisela 5 & $16.1 \mathrm{a}$ & $19.9 \mathrm{a}$ & $30.8 \mathrm{a}$ & $1098.4 \mathrm{~d}$ & $690.7 \mathrm{c}$ & $292.5 \mathrm{~b}$ & $5.6 \mathrm{a}$ & $8.9 \mathrm{a}$ & $19.8 \mathrm{a}$ & $14.6 \mathrm{a}$ & $28.8 \mathrm{a}$ & $105.3 \mathrm{~b}$ \\
\hline Edabriz & $20.5 \mathrm{~b}$ & $32.9 \mathrm{~b}$ & $28.1 \mathrm{a}$ & $696.4 \mathrm{c}$ & $498.2 \mathrm{~b}$ & $364.2 \mathrm{c}$ & $11.7 \mathrm{a}$ & $56.7 \mathrm{~b}$ & $23.1 \mathrm{ab}$ & $29.5 \mathrm{~b}$ & $66.0 \mathrm{~b}$ & $77.1 \mathrm{a}$ \\
\hline$P$-value & 0.0001 & 0.0001 & 0.0001 & 0.0001 & 0.0001 & 0.0001 & 0.0001 & 0.0001 & 0.0482 & 0.0001 & 0.0001 & 0.0001 \\
\hline
\end{tabular}

Means $(n=30)$ followed by the same letter are not significantly different at $P<0.05$ (Duncan's test).

Table 3 Xylem vessel diameter (VD), vessel frequency (VF), calculated relative hydraulic conductivity (RC) and vulnerability index (VI) of the stems of the five rootstocks in 1997

\begin{tabular}{lllll}
\hline Rootstock & VD $(\mu \mathrm{m})$ & $\begin{array}{l}\text { VF (ves- } \\
\left.\text { sels } \mathrm{mm}^{-2}\right)\end{array}$ & $\begin{array}{l}\mathrm{RC}\left(\mu \mathrm{m}^{4}\right. \\
\left.10^{6}\right)\end{array}$ & $\mathrm{VI}$ \\
\hline P. avium & $25.1 \mathrm{~b}$ & $369.9 \mathrm{~b}$ & $10.3 \mathrm{bc}$ & $67.8 \mathrm{~b}$ \\
CAB 11E & $29.6 \mathrm{c}$ & $218.9 \mathrm{a}$ & $11.4 \mathrm{c}$ & $135.4 \mathrm{~d}$ \\
Maxma 14 & $24.3 \mathrm{~b}$ & $326.5 \mathrm{~b}$ & $7.8 \mathrm{~b}$ & $74.3 \mathrm{c}$ \\
Gisela 5 & $18.6 \mathrm{a}$ & $371.8 \mathrm{~b}$ & $3.1 \mathrm{a}$ & $50.1 \mathrm{a}$ \\
Edabriz & $23.9 \mathrm{~b}$ & $460.5 \mathrm{c}$ & $11.2 \mathrm{c}$ & $51.9 \mathrm{a}$ \\
$P$-value & 0.0001 & 0.0001 & 0.0001 & 0.0001 \\
\hline
\end{tabular}

Means $(n=30)$ followed by the same letter are not significantly different at $P<0.05$ (Duncan's test).

Water relations and leaf gas exchange

There were significant $(P<0.05)$ differences in midday stem water potential $\left(\Psi_{\mathrm{MD}}\right)$ among the rootstocks in the two studied dates. In fact, trees on dwarfing rootstocks, Edabriz and Gisela 5, had lower $\Psi_{\mathrm{MD}}$, especially when grafted on Gisela 5 (Fig. 4). However, no significant $(P>0.05)$ differences were observed in morning stem water potential $\left(\Psi_{\mathrm{M}}\right)$ among rootstocks.

Regarding leaf gas exchange, as expected, $A$ correlated positively with $g_{\mathrm{s}}$ (Fig. 5). However, the coefficients of determination $\left(r^{2}\right.$, indicating the proportion of the variability in $A$ that is explained by $g_{\mathrm{s}}$ ) and the slopes of the linear regression were higher in dwarfing rootstocks than in invigorating ones. A comparison of all the slopes and the equations of the linear regression showed significant differences between the dwarfing and the invigorating rootstocks $(P<0.001)$, which suggest a strong regulation of photosynthesis by stomatal aperture on cherry trees grafted on Edabriz and Gisela 5.

Plant growth parameters

Trees on dwarfing rootstocks had significantly $(P<0.001)$ lower plant height and lower trunk diameters above and below the grafting point than trees on invigorating rootstocks (data not shown). In fact, for the same increase in plant height, the diameter of the trunk (above the grafting point) increased more in trees on invigorating rootstocks than in dwarfing rootstocks, as expressed by the slopes of the linear regression (Fig. 6). The coefficients of correlations between the trunk diameters below and above the grafting point were always high $(r>0.96 ; P<0.001)$. As a result, we found a similar relationship between the plant height and the trunk diameter below the grafting point, so only the first relationship is presented.

\section{Discussion}

Xylem structure and resistance to water transport among roots and stems

Plant anatomists have known for some time that xylem conduits (vessels and tracheids) within a plant tend to decrease
Table 4 Xylem vessel diameter (VD), vessel frequency (VF), calculated relative hydraulic conductivity (RC) and vulnerability index (VI) of the stems of 'Van' grafted onto five rootstocks in 2001-2002

\begin{tabular}{|c|c|c|c|c|c|c|c|c|}
\hline \multirow[t]{2}{*}{ Rootstock } & \multicolumn{2}{|c|}{$\mathrm{VD}(\mu \mathrm{m})$} & \multicolumn{2}{|c|}{$\mathrm{VF}\left(\right.$ vessels $\mathrm{mm}^{-2}$ ) } & \multicolumn{2}{|c|}{$\mathrm{RC}\left(\mu \mathrm{m}^{4} 10^{6}\right)$} & \multicolumn{2}{|l|}{ VI } \\
\hline & 2001 & 2002 & 2001 & 2002 & 2001 & 2002 & 2001 & 2002 \\
\hline$P$. avium & $14.8 \mathrm{~b}$ & $13.0 \mathrm{ab}$ & $564.3 \mathrm{~b}$ & $423.7 \mathrm{a}$ & $2.2 \mathrm{~b}$ & $0.83 \mathrm{a}$ & $26.3 \mathrm{~b}$ & $31.2 \mathrm{~d}$ \\
\hline CAB 11E & $13.4 \mathrm{a}$ & $12.3 \mathrm{a}$ & $605.8 \mathrm{~b}$ & $562.4 \mathrm{c}$ & $1.4 \mathrm{a}$ & $0.97 \mathrm{a}$ & $23.1 \mathrm{a}$ & $22.4 \mathrm{ab}$ \\
\hline Maxma 14 & $14.3 \mathrm{ab}$ & $13.2 \mathrm{~b}$ & $457.7 \mathrm{a}$ & $486.0 \mathrm{~b}$ & $1.4 \mathrm{a}$ & $1.05 \mathrm{a}$ & $31.5 \mathrm{~d}$ & $28.1 \mathrm{c}$ \\
\hline Gisela 5 & $13.7 \mathrm{a}$ & $12.2 \mathrm{a}$ & $488.8 \mathrm{a}$ & $502.9 \mathrm{~b}$ & $1.3 \mathrm{a}$ & $0.82 \mathrm{a}$ & $28.3 \mathrm{c}$ & $24.4 \mathrm{~b}$ \\
\hline Edabriz & $13.7 \mathrm{a}$ & $13.4 \mathrm{~b}$ & $550.1 \mathrm{~b}$ & $648.3 \mathrm{~d}$ & $1.4 \mathrm{a}$ & $1.58 \mathrm{~b}$ & $24.8 \mathrm{ab}$ & $20.8 \mathrm{a}$ \\
\hline$P$-value & 0.0073 & 0.0127 & 0.0001 & 0.0001 & 0.0004 & 0.0001 & 0.0001 & 0.0001 \\
\hline
\end{tabular}

Means $(n=30)$ followed by the same letter are not significantly different at $P<0.05$ (Duncan's test). 
Fig. 2 Scanning electron micrographs of roots and stems of Gisela 5 (dwarfing rootstock) and $\mathrm{CAB} 11 \mathrm{E}$ (invigorating rootstock). Scale bar $=50 \mu \mathrm{m}$
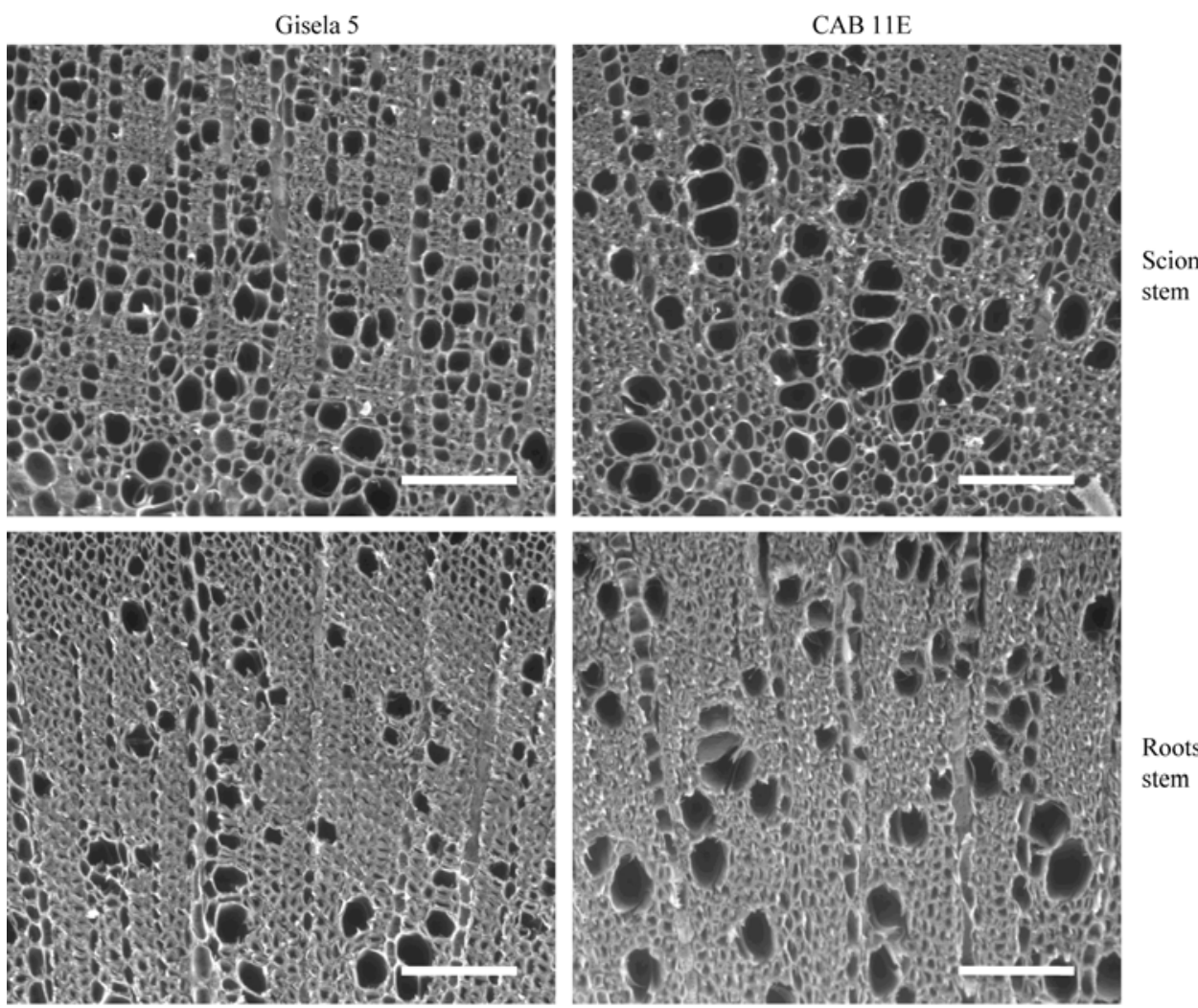

Rootstock stem

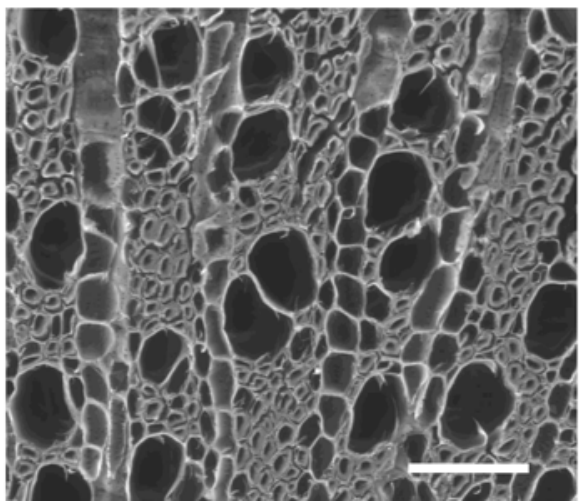

Fig. 3 Xylem/phloem thickness ratio of stems of Van grafted onto five rootstocks in 2001-2002. Means $(n=10)$ followed by the same letter are not significantly different at $P<0.05$ (Duncan's test)

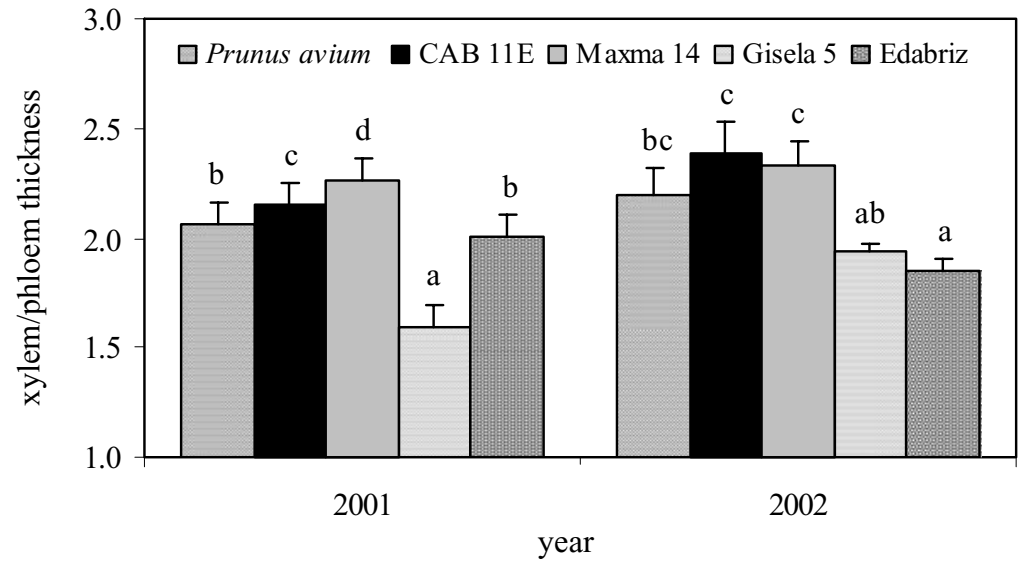




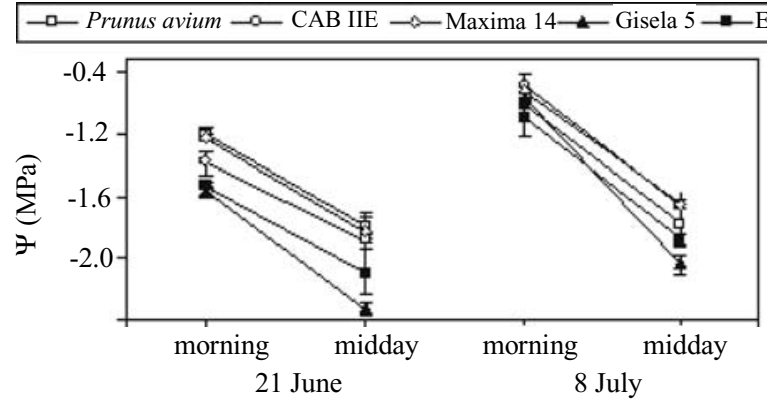

Fig. 4 Diurnal changes in stem water potential (MPa), measured at cherry ripeness period (two dates), for leaves of Van grafted onto five rootstocks. Within each diurnal period (morning: 09.00-10.00 h; midday: $14.00-15.00 \mathrm{~h})$ mean \pm S.E. $(n=8)$

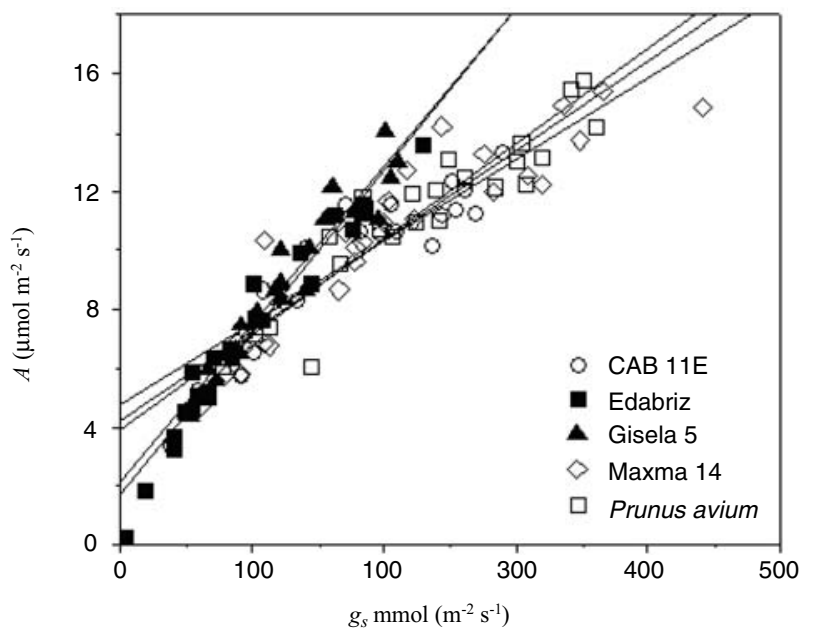

Fig. 5 Relationship between photosynthesis $(A)$ and stomatal conductance $\left(g_{\mathrm{s}}\right)$ in Edabriz $\left(A=1.627+0.055 g_{\mathrm{s}}, r^{2}=0.954, P<0.001\right)$, Gisela $5\left(A=2.111+0.054 g_{\mathrm{s}}, r^{2}=0.928, P<0.001\right)$, Maxma $14\left(A=4.763+0.028 g_{\mathrm{s}}, r^{2}=0.818, P<0.001\right), \mathrm{CAB} 11 \mathrm{E}$ $\left(A=3.854+0.032 g_{\mathrm{s}}, r^{2}=0.867, P<0.001\right)$ and $P$. avium $\left(A=4.239+0.030 g_{\mathrm{s}}, r^{2}=0.867, P<0.001\right)$. Measurements were taken throughout the diurnal period on June 21 and July 8, 2002

in diameter in acropetal direction, from roots to the terminal branches (Tyree and Zimmermann 2002). In accordance, our study showed that vessel lumen diameter decreased sharply from the roots to the terminal branches (Table 1) and in all Van-rootstock combinations (Tables 2-4). Differences in conduit diameter for root and stem xylem have been reported for a wide range of species. For trees in the Proteaceae, Pate et al. (1995) reported increases in VD between shallow roots and so-called sinker roots and along sinker roots with increasing depth. In the conifer Juniperus ashei Buchh., tracheids in shallow roots and deep roots were about three and four times wider, respectively, than tracheids in stems. Moreover, for the three dicotyledonous trees investigated, vessels in roots were an average of 1.5 (shallow) and 2.3 (deep) times wider than vessels in stems (McElrone et al. 2004). The large conduits of the roots, observed mainly in medium-size roots (Tables 1 and 3), are thought to be neces-

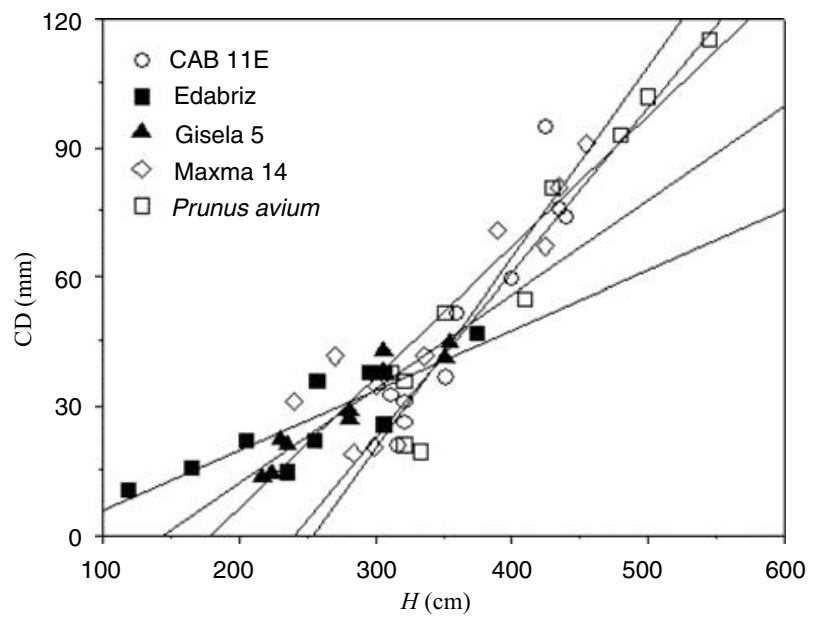

Fig. 6 Relationship between plant height $(H)$ and trunk diameter above the grafting point $(\mathrm{CD})$ in Edabriz $(\mathrm{CD}=-8.158+0.140 \mathrm{H}$, $\left.r^{2}=0.756, P<0.001\right)$, Gisela $5(\mathrm{CD}=-31.476+0.219 H$, $\left.r^{2}=0.904, P<0.001\right)$, Maxma $14(\mathrm{CD}=-54.645+0.305 H$, $\left.r^{2}=0.834, P<0.001\right)$, CAB 11E $(\mathrm{CD}=-112.434+0.443 H$, $\left.r^{2}=0.884, P<0.001\right)$ and $P$. avium $(\mathrm{CD}=-92.351+0.384 H$, $\left.r^{2}=0.928, P<0.001\right)$. Measurements were taken between 1998 and 2002 , in each dormancy period

sary to minimise the hydraulic resistance associated with the great path length from deep roots to the canopy (McElrone et al. 2004). Other reasons why xylem conduits are wider in deep roots than elsewhere within trees involve constraints that are related to the soil environment (North 2004). As discussed by McElrone et al. (2004), deep roots are supported by the soil and, unlike shallow roots, are relatively unaffected by mechanical forces acting on the shoot. The reduced need for the xylem to provide structural support allows deep roots to be specialised for transport, with fewer xylem fibers, fewer rays (Pate et al. 1995), more vessels or tracheids per transverse area, and conduits with larger lumens than in shallow roots and stems. Such specialization results not only in more efficient water uptake but also in reduced carbon allocation per unit length of root (North 2004).

Extensive research on species from a wide range of habitats generally supports the theory that xylem structure and function is optimised to balance the conflicting demands of xylem safety versus efficiency (Tyree et al. 1994; Pockman and Sperry 2000; Hacke and Sperry 2001). Despite the RC and VI being mathematically deduced, our results suggest a gain in hydraulic safety associated with a loss in hydraulic conductivity (Table 1). These results are consistent with the findings of McElrone et al. (2004) in stems, shallow roots and deep roots of four woody species. In a recent study, Pittermann et al. (2005) refer that the vulnerability to cavitation is dependent on the pit membrane, specifically on size of pores in the membrane, not on conduit diameters, per se. However, there is often a correlation, perhaps because the size of the vessel increases the area of the membrane, 
thereby increasing the probability that there will be higher pore sizes.

Xylem structure and resistance to water transport among rootstocks

Across rootstocks, VD was significantly larger in invigorating plants, i.e., Van grafted on $P$. avium, CAB $11 \mathrm{E}$ and Maxma 14, than vessels of trees on dwarfing Gisela 5 (Tables 2-4), which may be due to genetic differences, as it has been suggested that dwarfing rootstocks inherently produce smaller vessels (Beakbane and Thompson 1947). However, VD is not the only factor to influence xylem water transport. The dwarfed trees (grafted on Gisela 5 and Edabriz) had significantly lower xylem/phloem thickness ratio than trees on invigorating rootstocks (Fig. 3), mainly due to a low xylem thickness and not to a high phloem thickness (data not shown). Moreover, dwarfed cherry trees had smaller root systems than invigorating ones, as demonstrated in a previous study (Gonçalves et al. 2003). These observations are consistent with the view that clonally produced dwarfing rootstocks possess innate factors, such as lower xylem/phloem ratios and changes in xylem vessel anatomy (Simons 1986; Kurian and Iyer 1992), which might explain how they influence shoot behaviour when used in grafted plants. According to Atkinson et al. (2003), the development of vascular abnormalities (e.g., the production of excess callus cells in the graft union) may reduce xylem water transport and contribute to the dwarf stature. An alternative hypothesis for the apparent reduction in water transport through the graft union is that there is a reduction in transpiration of dwarfed trees due to smaller evaporative surface area or, perhaps, root-scion signalling molecules such as ABA (Olmstead et al. 2006).

We concluded that dwarfed plants, mainly grafted on Gisela 5, had adjustments in xylem structure and function that reduce hydraulic conductance and enhance hydraulic safety. Therefore, those trees had substantially lower VD and, consequently, lower RC. These findings are further supported by the observation that, as predicted by Poisseuille's law, although relative differences in VD between dwarfed and invigorating trees were similar at all organs tested, relative differences in RC (dependent on the fourth power of the vessel radius) were larger. Other factors, however, may contribute to conductivity changes: vessel transectional areas and length (Zimmermann and Jeje 1981), and so reduced vessel length may co-operate with reduced vessel diameter in decreasing xylem conductivity in dwarfed plants.

In all rootstock genotypes, VD and VF of the roots were inversely related (Table 2), similar to other plants (Carlquist 1988; Reyes-Santamaría et al. 2002). In spite of the differences in xylem hydraulic properties in roots, these features were similar among the stems of Van-rootstock combinations, suggesting an adjustment of these trees in adult phase.
It is common that genotypes with narrow and abundant vessels show low vulnerability values (Carlquist 1977). This indicates that among combinations, Van grafted on Gisela 5 and Edabriz probably have a safer water flow system because of their low VI (Tables 2-4). This supposition is supported by Hargrave et al. (1994) observations, who found that wider vessels are more susceptible to show dysfunction compared to vessels with narrower diameter. In addition, this interpretation supports the idea that Van on CAB 11E and Maxma 14 with wide vessels could be more susceptible to have embolism especially during periods of severe water stress (Hargrave et al. 1994). Although vulnerability to cavitation in $P$. avium increased with depth, deeper roots may not operate any closer to critically low xylem tensions because xylem water potential in deep roots is typically higher than in stems (McElrone et al. 2004).

In conclusion, xylem features of different rootstocks affected axial relative hydraulic conductance. However, rootstocks may also influence the radial conductance, according to several recent researchers (Atkinson et al. 2003; Basile et al. 2003a). Therefore, in future we intend to measure axial and radial conductance and correlate them with xylem properties and plant size.

Relationships between xylem structure and water relations, leaf gas exchange and growth

There is ample evidence that the structure of the plant hydraulic system - the hydraulic architecture-has the potential to limit water flow through plants, thus restricting their water balance, leaf gas exchange and growth (Tyree and Ewers 1991). Therefore, studying the differences in the hydraulic architecture of sweet cherry trees may help to select the best scion-rootstock combinations with regard to water availability in soils and specifically, in this study, how scion differs in growth when grafted on five differing-size controlling rootstocks.

The pattern in $\Psi$ of the different Van-rootstock combinations was the same in the two dates (Fig. 4), and these findings were also observed in the same cultivar-rootstock combinations in year 2003 by Gonçalves et al. (2006). The higher the RC in invigorating plants, the less negative is the stem water potential (Tables 2-4, Fig. 4). The same results were obtained by Lemoine et al. (2001) in three woody species.

Davis et al. (1999) and Schulbert et al. (1999) reported that water movement from the roots to the atmosphere is controlled by the conductivity of the water pathway components. Conductivities affecting water flow in the plant are hydraulic (root conductivity and shoot conductivity), and diffusive (stomatal conductance). In accordance, our study showed that smaller conduits of trees on Gisela 5 had lower relative hydraulic conductivity (Tables 2-4), and led to lower stomatal conductance and photosynthetic rate (Fig. 5). In fact, 
Franks (2004) referred that stomatal regulation of leaf gas exchange is directly influenced by the water status and hydraulic structure of the whole plant. Any change in transpiration rate will be translated almost immediately into a change in the water status of every leaf cell, including stomatal guard cells. Similarly, a change in the hydraulic properties will alter the water status of guard cells, and therefore stomatal conductance. The positive correlation between hydraulic and stomatal conductance has been also observed in several studies (Meinzer and Grantz 1990; Meinzer et al. 1995; Saliendra et al. 1995; Comstock 2000). Therefore, when xylem hydraulic conductance is reduced, stomatal conductance also decreases (Sperry et al. 1993; Hubbard et al. 2001; Cochard et al. 2002), indicating that hydraulic conductance to transpirational flux is an integral and dynamic component of the stomatal control mechanism (Franks 2004). Therefore, the lower $A$ in trees grafted on the dwarfing Edabriz and Gisela 5 was due to high stomatal limitations, represented by the low $g_{\mathrm{s}}$ in these two rootstocks (Fig. 5). The same results were observed in fifteen scion-rootstock combinations of sweet cherry in field-grown conditions (Gonçalves et al. 2006).

The lower $\Psi, g_{\mathrm{s}}$ and $A$ presented by the dwarfed trees led to lower vegetative growth (Figs. 4-6). Basile et al. (2003b) reported a positive correlation between integrated diurnal patterns of stem water potential and daily stem extension growth of peach trees on rootstocks with different size control potentials. They documented the effect of decreased water potential on shoot growth in a manner similar to previous works that linked water stress effects with plant growth in annual species (Hsiao 1973; Boyer 1985).

In conclusion, it is possible to say that much of this research has addressed the hydraulic limitation hypothesis, which proposes that reduced growth in trees grafted on dwarfing rootstocks may be linked to reductions in vessel diameters (and/or in xylem thickness and root system length) and consequently lower hydraulic conductivity, which in turn lead to reductions in stem water potential, ultimately decreasing stomatal conductance and photosynthesis. Nevertheless, measurements of the root and stem hydraulic conductivity and vulnerability are necessary to corroborate the theoretical calculations based on xylem anatomy.

Acknowledgments This work was partially financed by the projects PAMAF 2059 and AGRO 86. We express our gratitude to Ana Fraga, Donzília Costa and Rui Pires, for technical support in the laboratory and field experiment, and to Prof. José Luís Lousada for his advices in statistical analysis.

\section{References}

Alder NN, Sperry JS, Pockman WT (1996) Root and stem xylem embolism, stomatal conductance, and leaf turgor in Acer grandidentatum populations along a soil moisture gradient. Oecologia 105:293-301
Aloni R (1987) Vascular differentiation of tissues. Ann Rev Plant Physiol 38:179-204

Atkinson CJ, Else MA (2001) Understanding how rootstocks dwarf fruit trees. Compact Fruit Tree 34:46-49

Atkinson CJ, Else MA, Taylor L, Dover CJ (2003) Root and stem hydraulic conductivity as determinants of growth potential in grafted trees of apple (Malus pumila Mill.). J Exp Bot 385:12211229

Baas P, Chenglee L, Xinying Z, Keming C, Yuefen D (1984) Some effects of dwarf growth on wood structure. Int Assoc Wood Anat Bull 45:63-74

Basile B, Marsal J, Solari LI, Tyree MT, Bryla DR, DeJong TM (2003a) Hydraulic conductance of peach trees grafted on rootstocks with differing size-controlling rootstocks. J Hort Sci Biotech 78(6):768-774

Basile B, Marsal J, DeJong TM (2003b) Daily shoot extension growth of peach trees growing on rootstocks that reduce scion growth is related to daily dynamics of stem water potential. Tree Physiol 23:695-704

Beakbane AB, Thompson EC (1947) Anatomical studies of stems and roots of hardy fruit trees. IV. The root structure of some new clonal apple rootstocks budded with Cox's Orange Pippen. J Hort Sci 23:206-211

Boyer JS (1985) Water transport. Annu Rev Plant Physiol 36:473-516

Carlquist S (1977) Ecological factors in wood evolution: a floristic approach. Am J Bot 64:887-896

Carlquist S (1988) Comparative wood anatomy. Springer, Berlin, New York, p 436

Cochard H, Ewers FW, Tyree MT (1994) Water relations of a tropical vine-like bamboo (Rhipidocladum racemiflorum)—root pressures, vulnerability to cavitation and seasonal changes in embolism. J Exp Bot 45:1085-1089

Cochard H, Coll L, Le Roux X, Ameglio T (2002) Unravelling the effects of plant hydraulics on stomatal closure during water stress in walnut. Plant Physiol 128:282-290

Comstock JP (2000) Variation in hydraulic architecture and gas exchange in two desert sub-shrubs, Hymenoclea salsola (T. \& G.) and Ambrosia dumosa (Payne). Oecologia 125:1-10

Davis SD, Sperry JS, Hacke UG (1999) The relationship between xylem conduit diameter and cavitation caused by freezing. Am J Bot $86: 1367-1372$

Deysson G (1965) Éléments d'Anatomie des Plants Vasculaires. Société d'édition d'enseignement supérieur, Paris, p 261

Ewers FW (1985) Xylem structure and water conduction in conifer trees, dicot trees, and lianas. Int Assoc Wood Anat Bull 6:309317

Ewers FW, Zimmermann MH (1984) The hydraulic architecture of eastern hemlock (Tsuga canadensis). Can J Bot 62:940-946

Fahn A, Werker E, Baas P (1986) Wood anatomy and identification of trees and shrubs from Israel and adjacent regions. Isr Acad Sci Hum, Jerusalem, Israel, p 1040

Franks PJ (2004) Stomatal control and hydraulic conductance, with special reference to tall trees. Tree Physiol 24:865-878

Gonçalves B, Santos A, Silva AP, Moutinho-Pereira J, Torres-Pereira JMG (2003) Effect of pruning and plant spacing on the growth of cherry rootstocks and their influence on stem water potential of sweet cherry trees. J Hort Sci Biotech 78(5):667-672

Gonçalves B, Moutinho-Pereira J, Santos A, Silva AP, Bacelar E, Correia C, Rosa E (2006) Scion-rootstock interaction affects the physiology and fruit quality of sweet cherry tree. Tree Physiol 26:93104

Hacke UG, Sperry JS (2001) Functional and ecological xylem anatomy. Perspect Plant Ecol Evol Syst 4:97-115

Hargrave KR, Kolb KJ, Ewers FW, Davis SD (1994) Conduit diameter and drought-induced embolism in Salvia mellifera Greene (Labiatae). New Phytol 126:695-705 
Hess T, Sachs T (1972) The influence of a mature leaf on xylem differentiation. New Phytol 71:903-914

Hsiao TC (1973) Plant responses to water stress. Annu Rev Plant Physiol 24:519-570

Hubbard RM, Ryan MG, Stiller V, Sperry JS (2001) Stomatal conductance and photosynthesis vary linearly with plant hydraulic conductance in ponderosa pine. Plant Cell Environ 24:113121

Jackson RB, Sperry JS, Dawson TE (2000) Root water uptake and transport: using physiological processes in global predictions. Trends Plant Sci 5:482-488

Jones HG (1990) Physiological aspects of the control of water status in horticultural crops. HortScience 25:19-26

Kavanaugh KL, Bond BJ, Aitken SN, Gartner BL, Knowe S (1999) Shoot and root vulnerability to xylem cavitation in four populations of Douglas-fir seedlings. Tree Physiol 19:31-37

Kramer P, Boyer J (1995) Water relations of plants and soils. Academic Press, San Diego, CA, USA, p 495

Kurian RM, Iyer CPA (1992) Stem anatomical characters in relation to tree vigour in mango (Mangifera indica L.). Scientia Hort 50:245253

Lemoine D, Peltier JP, Marigo G (2001) Comparative studies of the water relations and the hydraulic characteristics in Fraxinus excelsior, Acer pseudoplatanus and A. opalus trees under soil water contrasted conditions. Ann For Sci 58:723-731

Lovisolo C, Schubert A (1998) Effects of water stress on vessel size and xylem hydraulic conductivity in Vitis vinifera L. J Exp Bot 49:693-700

Martínez-Vilalta J, Prat E, Oliveras I, Piñol J (2002) Xylem hydraulic properties of roots and stems of nine Mediterranean woody species. Oecologia 133:19-29

McCutchen H, Schackel KA (1992) Stem-water potential as a sensitive indicator of water stress in prune trees (Prunus domestica L.). J Am Soc Hort Sci 117:607-611

McDowell NG, Phillips N, Lunch C, Bond BJ, Ryan MG (2002) An investigation of hydraulic limitation and compensation in large, old Douglas-fir trees. Tree Physiol 22:763-774

McElrone AJ, Pockman WT, Martínez-Vilalta J, Jackson RB (2004) Variation in xylem structure and function in stems and roots of trees to $20 \mathrm{~m}$ depth. New Phytol 163:507-517

Meinzer FC, Grantz DA (1990) Stomatal and hydraulic conductance in growing sugarcane: stomatal adjustment to water transport capacity. Plant Cell Environ 13:383-388

Meinzer FC, Goldstein G, Jackson P, Holbrook NM, Guttierez MV, Cavelier J (1995) Environmental and physiological regulation of transpiration in tropical forest gap species: the influence of boundary layer and hydraulic properties. Oecologia 101:514 522

Mencuccini M, Grace J (1996) Hydraulic conductance, light interception and needle nutrient concentration in scots pine stands and their relations with net primary productivity. Tree Physiol 16:459-468

North GB (2004) A long drink of water: how xylem changes with depth. New Phytol 163:449-451

Olmstead MA, Lang NS, Lang GA, Ewers FW, Owens SA (2006) Examining the vascular pathway of sweet cherries grafted onto dwarfing rootstocks. HortScience 41(3):674-679

Parkinson M, Yeoman MM (1982) Graft union formation in cultured, explanted internodes. New Phytol 91:711-719

Pate JS, Jeschke WD, Aylward MJ (1995) Hydraulic architecture and xylem structure of the dimorphic root systems of SouthWest Australian species of the Proteaceae. J Exp Bot 46:907915

Pittermann J, Sperry JS, Hacke UG, Wheeler JK, Sikkema EH (2005) Torus-margo pits help conifers compete with angiosperms. Science 310:1924-1925
Pockman WT, Sperry JS (2000) Vulnerability to xylem cavitation and the distribution of Sonoran Desert vegetation. Am J Bot 87:12871299

Pockman WT, Sperry JS, O'Leary JW (1995) Sustained and significant negative water pressure in xylem. Nature 378:715-716

Reyes-Santamaría I, Terrazas T, Barrientos-Priego AF, Trejo C (2002) Xylem conductivity and vulnerability in cultivars and races of avocado. Scientia Hort 92:97-105

Ryan MG, Bond BJ, Law BE, Hubbard RM, Woodruff D, Cienciala E, Kučera J (2000) Transpiration and whole-tree conductance in ponderosa pine trees of different heights. Oecologia 124:553-560

Saliendra NZ, Sperry JS, Comstock JP (1995) Influence of leaf water status on stomatal response to hydraulic conductance, atmospheric drought, and soil drought in Betula occidentalis. Planta 196:357366

Savidge RA (1988) Auxin and ethylene regulation of diameter growth in trees. Tree Physiol 4:401-414

Schulbert A, Lovisolo C, Peterlunger E (1999) Shoot orientation affects vessel size, shoot hydraulic conductivity and shoot growth rate in vities vinifera L. Plant Cell Environ 22:197-204

Sekse L (1998) Fruit cracking mechanisms in sweet cherries (Prunus avium L.)—a review. Acta Hort 468:637-648

Simons RK (1986) Graft-union characteristics as related to dwarfing in apple (Malus domestica Borkh.). Acta Hortic 160:57-66

Simons RK, Chu MC (1984) Tissue development within the graft union as related to dwarfing in apple. Acta Hortic 146:203-210

Soumelidou K, Battey NH, John P, Barnett JR (1994) The anatomy of the developing bud union and its relationship to dwarfing in apple. Ann Bot 74:605-611

Sperry JS, Tyree MT (1990) Water-stress induced xylem embolism in three species of conifers. Plant Cell Environ 13:427-436

Sperry JS, Saliendra NZ (1994) Intra- and inter-plant variation in xylem cavitation in Betula occidentalis. Plant Cell Environ 17:12331241

Sperry JS, Alder NN, Eastlack SE (1993) The effect of reduced hydraulic conductance on stomatal conductance and xylem cavitation. J Exp Bot 44:1075-1082

Syvertsen JP, Graham JH (1985) Hydraulic conductivity of roots, mineral nutrition, and leaf gas exchange of citrus rootstocks. J Am Soc Hort Sci 110:865-869

Tyree MT, Ewers FW (1991) The hydraulic architecture of trees and other woody plants. New Phytol 119:345-360

Tyree MT, Zimmermann MH (2002) Xylem structure and the ascent of sap. Springer-Verlag, Heidelberg, Germany, p 297

Tyree MT, Snyderman DA, Wilmot TR, Machado JL (1991) Water relations and hydraulic architecture of a tropical tree (Schefflera morototoni). Tree Physiol 96:1105-1113

Tyree MT, Davis SD, Cochard H (1994) Biophysical perspectives of xylem evolution: is there a tradeoff of hydraulic efficiency for vulnerability to dysfunction? Int Assoc Wood Anat J 14:335-360

von Caemmerer S, Farquhar GD (1981) Some relationships between the biochemistry of photosynthesis and gas exchange of leaves. Planta 153:376-387

Williams M, Rastetter EB, Fernandes DN, Goulden ML, Wofsy SC, Shaver GR, Melillo JM, Munger JW, Fan S-M, Nadelhoffer KJ (1996) Modelling the soil-plant-atmosphere continuum in a Quercus-Acer stand at Harvard Forest: the regulation of stomatal conductance by light, nitrogen and soil plant hydraulic properties. Plant Cell Environ 19:911-927

Zimmermann MH (1978) Hydraulic architecture of some diffuseporous trees. Can J Bot 56:2286-2295

Zimmermann MH (1983) Xylem Structure and the ascent of sap. Berlin, Springer-Verlag, p 143

Zimmermann MH, Jeje AA (1981) Vessel-length distribution in stems of some American woody plants. Can J Bot 59:1882-1892 